\title{
China's Economic Development and Future Trends under the Impact of COVID-19
}

\author{
Yue Wang* \\ Northeast Forestry University, Harbin, China \\ *Guanghua.ren@gecacademy.cn
}

\begin{abstract}
The outbreak of COVID-19 pandemic in 2020 has had a great impact on the economic environment. This article selects GDP and major economic data that constitute GDP in recent years to analyze the impact of the pandemic on China's economy. This article compares the changes in economic data in the first half and the second half of the year 2020 to reveal the economic meaning behind the data. Analysis shows that in the first half of 2020, affected by the pandemic, economic data has dropped significantly, and the economy has gradually recovered in the second half of the year, and economic data has rebounded. Specifically, the growth rate of the added value of the industrial enterprises above designated size turned from negative to positive and returned to the prepandemic level in the second half of the year; total retail sales first fell and then rose; the growth rate of fixed assets and foreign investment turned from a decline to an increase; the total export of goods achieved growth; the annual GDP achieved positive growth and sustained economic development. Looking forward to 2021, the annual GDP growth rate is expected to be around $8 \%$. Comprehensive data analysis has concluded that: controlling the pandemic is a prerequisite for economic growth; new infrastructure is a strong driving force for economic development, and the "double cycle" is the new pattern of China's economic development in the future.
\end{abstract}

Keywords: COVID-19; GDP; Industrial Production; Social Consumption; Fixed Assets and Foreign Investment; Goods Export Trade.

\section{Introduction}

The outbreak of COVID-19 not only threatened the safety of people's lives, but also had a major impact on economic development. In order to protect the health of the people, government has adopted strict prevention and control measures. The initial outbreak of the pandemic coincided with the 2020 spring break, and the resumption of production and work after the spring break was originally planned to be postponed. However, the market economy has been hit to a certain extent in all environments, from production, supply to consumption. At the same time, during the pandemic, due to the changes in people's lifestyles, social environment, and international environment, new economic development opportunities have also arisen. The impact of the pandemic on the economy can be analyzed from a macro perspective. Through analysis and comparison of GDP data, the relationship between the pandemic and the economy can be reflected. Macroeconomic indicators can more closely reflect economic conditions at all levels. Whether it is industrial development, social consumption, fixed asset investment in the whole society, or national imports and exports, it can all be reflected through a comparative analysis of macroeconomic indicator data.

This article uses comparative analysis to analyze and interpret the economic data in the first half and the second half of 2020. Economic data changes during the pandemic can be directly reflected, and fluctuations of economic data in a comprehensive macroeconomic policy are analyzed. The particularity of the pandemic is a new challenge to the national economy. In the first quarter of 2020, China's economy fell by $6.8 \%$ year-on-year. This was the first quarterly negative economic growth since the establishment of the quarterly GDP accounting system in 1992. The decline far exceeded the impact of the 1998 Asian financial crisis and the 2008 international financial crisis on China's economic growth [1]. In view of COVID-19 and the economic environment at home and abroad, the significance of the new economic development concepts and guidelines is self-evident. Based on the economic data and economic development in 2020, this article predicts the rate of economic 
development in 2021, and concludes China's economic development under the pandemic, which will inspire future economic development.

This article is organized as follows: The first part is the introduction; the second part is the outline of the COVID-19 pandemic, which mainly introduces the mutation trend of the pandemic in 2020 in the background of the outbreak; the third part is to reveal China's macro economy in 2020 through the analysis of economic data The operation situation of the company is mainly analyzed from the perspectives of GDP, industrial production, social consumption, fixed assets and foreign investment, and import and export of goods; the fourth part is the outlook and forecast of China's economic situation in 2021; the fifth part is the pandemic situation based on the above analysis under the indicators of economic development.

\section{China's Economic Development in the Context of Pandemic Situation from the Perspective of Economic Data}

\subsection{Economic Growth}

Economic growth can be reflected in GDP. The GDP data for the first and second quarters of 2020 are as follows. Affected by the pandemic, the GDP in the first quarter fell by $6.8 \%$ year-on-year, the second quarter increased by 3.2\% year-on-year, and the GDP in the first half of the year decreased by $1.6 \%$ year-on-year [2]. It can be seen that due to the impact of the pandemic, the GDP in the first quarter has dropped significantly, and since the second quarter, the GDP has achieved positive growth over the same period last year, as shown in Table 1.

Table 1. Preliminary accounting data of GDP in the first and second quarters of 2020

\begin{tabular}{|l|c|c|c|c|c|c|}
\hline \multirow{2}{*}{ GDP } & \multicolumn{2}{|c|}{ Absolute value (100 million yuan) } & \multicolumn{3}{c|}{ Increased over the same period of last year (\%) } \\
\cline { 2 - 7 } & $\boldsymbol{Q 1}$ & $\boldsymbol{Q 2}$ & $\boldsymbol{H 1}$ & $\boldsymbol{Q 1}$ & $\boldsymbol{Q 2}$ & $\boldsymbol{H 1}$ \\
\hline
\end{tabular}

a. Source: China Bureau of Statistics

In the second half of the year, GDP gradually recovered from a quarterly perspective. The yearon-year growth rate of GDP in the third and fourth quarters was $4.9 \%$ and $6.5 \%$, respectively. From the cumulative value, the GDP for the whole year of 2020 will grow by $2.3 \%$ [3]. Compared with the sharp decline in the first half of the year, the year-on-year growth rate of GDP in the second half of the year gradually picked up, $6.5 \%$ in the fourth quarter has reached the level before the pandemic, as shown in Table 2.

Table 2. 2016-2020 year on year growth rate of GDP (\%)

\begin{tabular}{|c|c|c|c|c|}
\hline \multirow{2}{*}{ Year } & \multicolumn{4}{|c|}{ Growth rate of GDP (\%) } \\
\cline { 2 - 5 } & $\boldsymbol{Q 1}$ & $\mathbf{Q 2}$ & $\boldsymbol{Q 3}$ & $\boldsymbol{Q 4}$ \\
\hline $\mathbf{2 0 1 6}$ & $6.9^{\mathrm{b}}$ & 6.8 & 6.8 & 6.9 \\
\hline $\mathbf{2 0 1 7}$ & 7.0 & 7.0 & 6.9 & 6.8 \\
\hline $\mathbf{2 0 1 8}$ & 6.9 & 6.9 & 6.7 & 6.5 \\
\hline $\mathbf{2 0 1 9}$ & 6.3 & 6.0 & 5.9 & 5.8 \\
\hline $\mathbf{2 0 2 0}$ & -6.8 & 3.2 & 4.9 & 6.5 \\
\hline
\end{tabular}

b. Source: China Bureau of Statistics

Compared with the data in recent years, it can reflect the impact of the pandemic on the economy. The quarterly cumulative year-on-year growth rate of GDP from 2016 to 2019 has been maintained at a relatively stable 6\%-7\% [4]. Especially in 2018-2019, facing the pressure of the "China-US trade war" on import and export trade, GDP still maintained a relatively stable growth rate. In the first quarter of 2020, there was a negative growth, which is very abnormal. This shows the impact of the pandemic on the economy. Looking at the whole year, the GDP growth rate of $2.3 \%$ is very pleasant. 
The special national policy is an important reason for the positive growth of GDP throughout the year. In the 2020 government work report, for the first time, there is no economic growth target. In the face of the pandemic, the shrinkage of the world economy has become an inevitable fact. Under this circumstance, economic growth can no longer be regarded as the only development goal, and while adhering to the concept of "life first", it is necessary to seek development. Although there is no clear target for economic growth, the Politburo meeting of the Central Committee proposed to do a solid job of "six stabilities" and fully implement the task of "six guarantees". Six guarantees refer to stable employment, stable finance, stable foreign trade, stable foreign investment, stable investment, and stable expected work. The six guarantees are to ensure employment, basic people's livelihood, market players, food and energy security, industrial chain supply chain stability, and the operation of the grassroots. Although there is no clear target for economic growth, there are targets for other indicators. These small targets have pointed out the direction for economic stability and development to a certain extent. For example, the target for new urban jobs in 2020 is 9 million people. Statistics from November show that 10.99 million new jobs in urban areas have been realized from January to November, which is ahead of schedule [5].

National macro policies also play an important role in economic recovery. In terms of fiscal policy, measures have been taken to strengthen funding protection, reduce taxes and fees, and discount loan interest. On the one hand, tax cuts and fee reductions increase the personal disposable income of residents; on the other hand, it stimulates consumer spending, which in turn promotes economic growth. In terms of monetary policy, measures have been taken to reduce the deposit reserve ratio, re-loan and re-discount, and innovate monetary policy tools that directly reach the real economy to maintain reasonable and sufficient liquidity [6]. Frequent looser monetary policies have alleviated the liquidity shortage in the real economy. At the end of December, the balance of M2 was 218.68 trillion yuan, a year-on-year increase of $10.1 \%$. The scale of social financing was 34.86 trillion yuan at the end of December, an increase of 9.19 trillion yuan over the previous year [7]. These measures have effectively hedged the impact of the pandemic on the economy and ensured the steady recovery of the economy.

\subsection{Industrial Production}

In the first quarter of 2020, the added value of industrial enterprises above designated size all showed negative growth. Since April, the year-on-year growth rate has turned positive. In the first quarter, the value-added of the industrial enterprises above designated size fell by $6.8 \%$. In the second quarter, the decline in the first quarter was reversed and turned to an increase of $4.4 \%$.

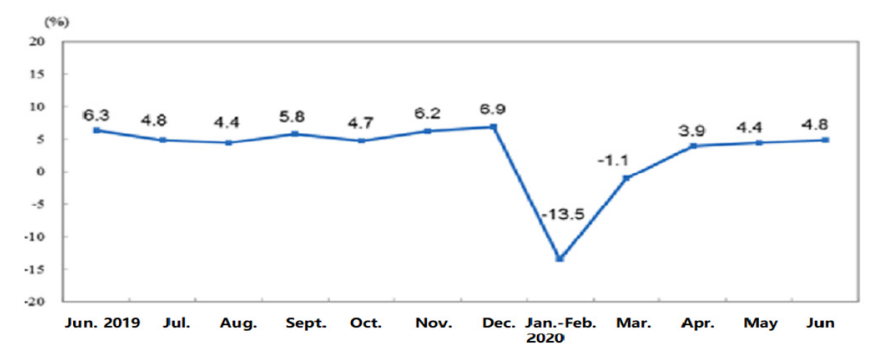

Figure 1. Year-on-year growth rate of industrial added value above designated size

Judging from the cumulative data, the value added of industries above designated size in the first half of the year fell by $1.3 \%$ year-on-year, mainly because the decline in the first quarter could not be compensated by the growth in the second quarter [8]. In the three major sectors of industry, mining, manufacturing, and electricity, heat, gas, and water production and supply, the cumulative year-onyear growth in the first half of the year were negative. Only the high-tech manufacturing industry in manufacturing industry grew by $4.5 \%$, accounting for scale. The above industrial added value accounted for $14.7 \%$, an increase of $0.9 \%$ over the same period last year, as shown in Table 3 . 
Table 3. Added value of industries above Designated Size in June and January June

\begin{tabular}{|c|c|c|}
\hline & \multicolumn{2}{|c|}{ Yearly growth rate (\%) } \\
\cline { 2 - 3 } & Jun. & Jan.-Jun. \\
\hline The added value of industries above designated size & $4.8^{\mathrm{c}}$ & -1.3 \\
\hline Three categories: & & -1.1 \\
\hline Mining & 1.7 & -1.4 \\
\hline Manufacturing & 5.1 & 4.5 \\
\hline -high tech manufacturing industry & 10 & -0.9 \\
\hline
\end{tabular}

c. Source: China Bureau of Statistics

In the second half of the year, the added value of the industrial enterprises above designated size has maintained positive growth, and the year-on-year growth rate has steadily picked up (Figure 2). The index values from September to December have reached and exceeded the level of last December. The added value of industries above designated size increased by $2.8 \%$ over the previous year for the whole year. Among them, industrial production has accelerated, high-tech manufacturing and equipment manufacturing have grown rapidly, and new industries and new products have flourished. In 2020, the added value of the equipment manufacturing industry will increase by $6.6 \%$ over the previous year, which is 3.8 points higher than the average level of all regulated industries. Its contribution rate to the growth of all regulated industries will reach $70.6 \%$ [9]. Both the third and fourth quarters achieved double-digit growth. In 2020, the added value of high-tech manufacturing above designated size will increase by $7.1 \%$ over the previous year, 4.3 percentage points faster than that of all industries above designated size. The growth rate of emerging products, such as $3 \mathrm{D}$ printing equipment, smart watches, and civilian drones, has more than doubled. The production of products has increased significantly, and the market demand is great [10].

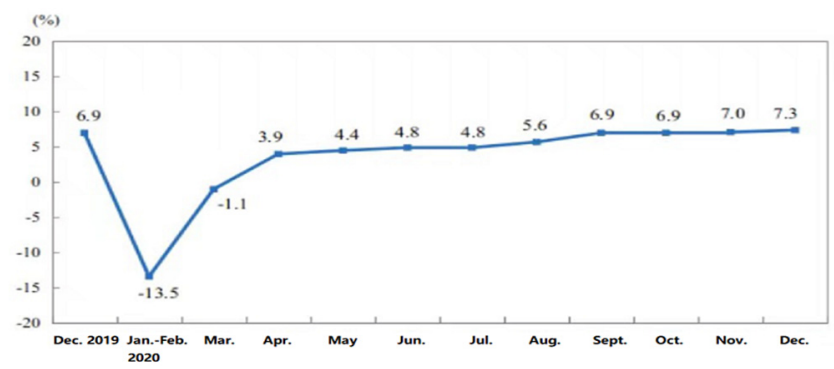

Figure 2. Year-on-year growth rate of industrial added value above designated size

Since the concept of "new infrastructure" was put forward, technological innovation has always been the direction of development. The new infrastructure mainly includes three aspects: information infrastructure, integrated infrastructure, and innovation infrastructure [11]. During the pandemic, high-tech industries have provided convenience for living and working at home when people are confined to their homes. The development of 5G, artificial intelligence, big data, and other technologies provides people with platforms for online shopping, remote office, and online education. The application of Internet technology will be an indispensable part of future economic development. Due to the restrictions of the pandemic, people use the Internet more and reduce the concentration of offline people. While some traditional offline companies have been hit, it has also given birth to development opportunities for online service companies.

\subsection{Social Consumption}

From January to February, the total retail sales of consumer goods fell by $20.5 \%$ year-on-year, which is a very large drop compared to the monthly growth rate of $7 \%-9 \%$ in 2019 . The monthly growth rate in the first half of the year was negative. From January to June, the total retail sales of 
Volume 17 (2022)

consumer goods were 1,72256 billion yuan, a year-on-year decrease of $11.4 \%$. Among them, the retail sales of consumer goods other than automobiles were 15.5869 trillion yuan, down $10.9 \%$ [12].

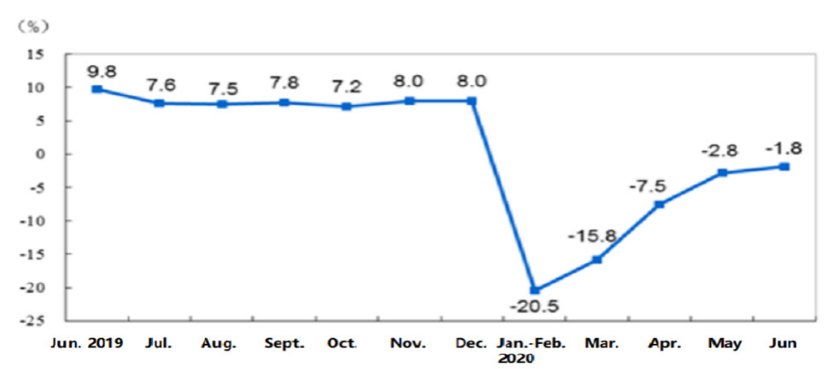

Figure 3. Year-on-year growth rate of total retail sales of social consumer goods

Since August 2020, the total retail sales of consumer goods have maintained a positive year-onyear growth (Figure 4). The total retail sales of consumer goods in the whole year were 391981 trillion yuan, a decrease of $3.9 \%$ over the previous year. Among them, the retail sales of consumer goods other than automobiles were 3,525.6 billion yuan, down 4.1\%. In 2020, national online retail sales reached 11,760.1 billion yuan, which is an increase of $10.9 \%$ over the previous year. Among them, the online retail sales of physical goods were 975.9 billion yuan, an increase of $14.8 \%$, accounting for $24.9 \%$ of the total retail sales of consumer goods; among the online retail sales of physical goods, food, clothing, and consumer goods increased by $30.6 \%$ and $5.8 \%$ respectively and $16.2 \%$ (Table 4).

Table 4. Total retail sales of social consumer goods in 2020

\begin{tabular}{|c|c|c|}
\hline & Total amount $\mathbf{( 1 0 0}$ million yuan) & Yearly growth (\%) \\
\hline Total retail sales of consumer goods & $391981^{\mathrm{d}}$ & -3.9 \\
\hline -Online retail sales of physical goods & 97590 & 14.8 \\
\hline
\end{tabular}

d. Source: China Bureau of Statistics

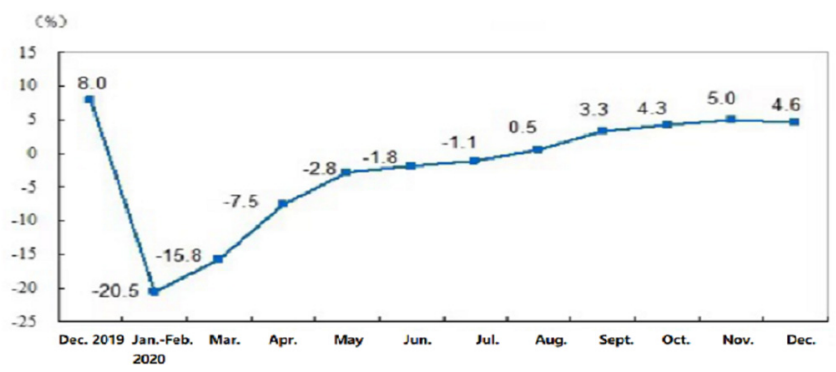

Figure 4. Year-on-year growth rate of total retail sales of consumer goods

Affected by the pandemic, traditional offline consumption has been hit hard. This is reflected in the negative year-on-year growth rate of total retail sales of consumer goods in the first quarter of the three-month period in the chart. It is worth noting that although the offline economy has suffered setbacks, the online digital economy has more room for development. People's daily necessities have become very tight due to travel restrictions, and online shopping has become the first choice for people to shop [13]. Therefore, with the development of the online economy, the economic recession caused by insufficient consumption has been cushioned to a certain extent. At the same time, with the further control of the pandemic, a safer offline consumption environment will give consumers more room to choose, and the gradual recovery of offline consumption will also gradually improve social consumption. As online shopping orders generate a large number of logistics and transportation demand, the logistics industry generates a large number of transportation jobs, which drives the demand for heavy trucks and other automobiles, and automobile sales grow.

The development of the digital economy is the foundation for the growth of online retail sales. The digital economy has spawned various new economic formats and new business models, leading the 
employment structure and new trends in career development [14]. With the advancement of technology, online shopping has become popular, which positively affects stimulating online consumption. The pandemic has prompted people to spend more time at home and the emergence of new formats such as live broadcast of goods. Therefore, houses, cars, and other products that were previously impossible to appear online can also be traded online have developed rapidly.

\subsection{Fixed Assets and Foreign Investment}

From January to February 2020, the national fixed asset investment grew at a year-on-year growth rate of $-24.5 \%$, while maintaining a growth rate of $5 \%-6 \%$ in each month of 2019 . From January to June, the national investment in fixed assets (excluding rural households) was 28,160.3 billion yuan, a year-on-year decrease of 3.1\% (Figure 5). In the first half of the year, investment in high-tech industries increased by $6.3 \%$, and fell by $12.1 \%$ in the first quarter; among them, investment in hightech manufacturing and high-tech service industries increased by $5.8 \%$ and $7.2 \%$, respectively. In the high-tech manufacturing industry, investment in the pharmaceutical manufacturing industry, computer, and office equipment manufacturing industry increased by $13.6 \%$ and $8.2 \%$, respectively; in the high-tech service industry, investment in the e-commerce service industry and technological achievement transformation service industry increased by $32.0 \%$ and $21.8 \%$ respectively. From January to June, foreign investment increased by $3.5 \%$ [15].

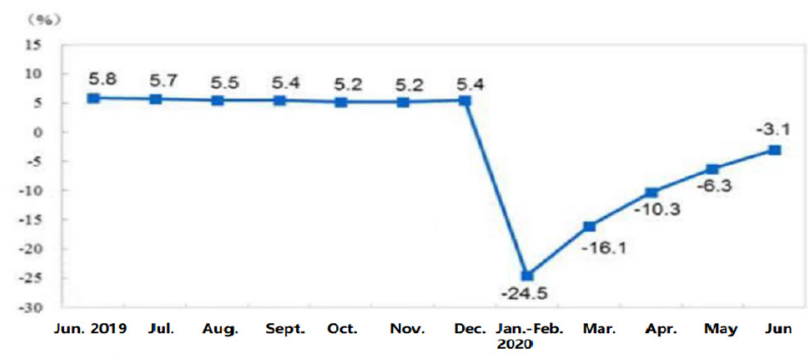

Figure 5. Year-on-year growth of fixed asset investment (excluding farmers)

In the second half of the year, the year-on-year growth rate of fixed asset investment rebounded steadily. Since September, fixed asset investment has achieved positive year-on-year growth. From January to December 2020, the national investment in fixed assets (excluding rural households) was $51,900.7$ billion yuan, an increase of $2.9 \%$ over the previous year (Figure 6). Among them, the investment of foreign enterprises increased by $10.6 \%$ over the previous year.

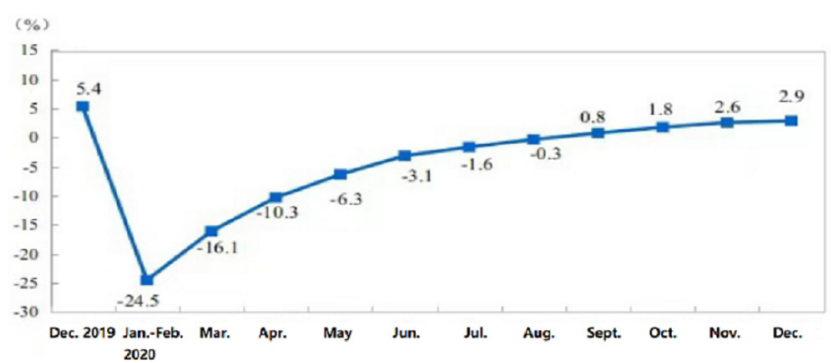

Figure 6. Year-on-year growth of fixed asset investment (excluding farmers)

In the first half of the first half of the country's total fixed asset investment fell year-on-year, the high-tech industry investment still maintained rapid growth, mainly due to the "new infrastructure" policy. The advancement of core technology is conducive to promoting industrial upgrading and providing more valuable products to the market, thereby stimulating market consumption and promoting high-quality economic growth. Thanks to policy support and guidance, high-tech industries have received more investment, which will enable continued growth in investment in hightech industries when the economy affected by the pandemic in 2020 is not optimistic. New infrastructure investment represented by $5 \mathrm{G}$ base stations, charging piles, and UHV power grids has 
brought rapid growth in investment in the power and gas industry and has played an important role in stable investment in 2020 [16].

Facing the impact of the COVID-19 pandemic on the economy, the National Development and Reform Commission and the Ministry of Commerce released the 2020 version of the negative list for foreign investment access. The release of the negative list is a deletion of the previous list to attract more foreign investment and inject more funds for economic development. The main changes are to speed up opening up key areas of the service industry; relax access to manufacturing and agriculture; continue to open pilot projects in the pilot free trade zone. By removing some of the negative list restrictions, the financial, manufacturing and agricultural sectors will attract more foreign investment. Even if affected by the pandemic, the cumulative fixed asset investment of foreign-invested enterprises from January to December 2020 will still increase by $10.6 \%$ over last year (Table 5).

Table 5. Growth rate of fixed assets investment (excluding farmers) in 2020

\begin{tabular}{|c|c|}
\hline & Yearly increase (\%) \\
\hline Fixed assets investment (excluding farmers) & $2.9^{\mathrm{e}}$ \\
\hline -domestic enterprises & 2.8 \\
\hline -Hong Kong, Macao and Taiwan investment enterprises & 4.2 \\
\hline -Foreign invested enterprises & 10.6 \\
\hline
\end{tabular}

e. China Bureau of Statistics

\subsection{Goods Export Trade}

According to customs statistics, in the first half of this year, the total value of China's imports and exports of goods trade was 14.24 trillion yuan, down 3.2\% year-on-year, and the rate of decline narrowed by 1.7 percentage points compared with the previous five months. Among them, exports were 7.71 trillion yuan, down 3\%; imports were 6.53 trillion yuan, down 3.3\% (Table 6). The electronics manufacturing industry is closely linked, which has driven a substantial increase in the import and export of related products. As part of the global electronics manufacturing industry chain, China imported 226.81 billion yuan of integrated circuits from ASEAN in the first half of this year, an increase of $23.8 \%$, accounting for $24.2 \%$ of the total value of imports from ASEAN, and exports of integrated circuits to ASEAN were 89.48 billion yuan, an increase of $29.1 \%$, accounting for $7.8 \%$ of total exports to ASEAN [17].

Table 6. Import and export trade volume and year-on-year growth rate

\begin{tabular}{|c|c|c|}
\hline & $H 1$ & 2020 \\
\hline Total import (RMB 100 million) & $6.53^{\mathrm{f}}$ & 14.23 \\
\hline Yearly growth of import (\%) & -3.3 & -0.7 \\
\hline Total export (RMB 100 million) & 7.71 & 17.93 \\
\hline Yearly growth of export (\%) & -3 & 4 \\
\hline Total import and export (RMB 100 million) & 14.34 & 32.16 \\
\hline Yearly growth of import and export (\%) & 3.2 & 1.9 \\
\hline
\end{tabular}

f. General Administration of Customs of China

In 2020, the total value of China's import and export of goods trade was 32.16 trillion yuan, an increase of $1.9 \%$ over 2019, a record high. Among them, exports were 17.93 trillion yuan, an increase of $4 \%$; imports were 14.23 trillion yuan, a decrease of $0.7 \%$; the trade surplus was 3.7 trillion yuan, an increase of $27.4 \%$. Under multiple pressures such as the impact of the pandemic and unilateral protectionism, China's foreign trade in the first quarter of 2020 started with a year-on-year decline of 
6.5\%. In the next second quarter, China, which took the lead in containing the pandemic and resuming work and production, ushered in a rebound in foreign trade, and the year-on-year decline narrowed to $0.2 \%$ in the current quarter. Entering the third quarter, China's foreign trade continued to pick up. By the end of the quarter, the cumulative growth rate reached $0.7 \%$, ushering in the first time this year from negative to positive. In the fourth quarter, the positive momentum of foreign trade remained unabated, and the growth rate showed an accelerating trend. Throughout the year, the trend of opening low and going high is obvious [18].

There were two reasons for the year-on-year decline in exports in the first half of the year. On the one hand, in the face of the impact of the pandemic, the resumption of production and work of foreign trade companies has been affected, resulting in companies unable to complete production and provide services on schedule. On the other hand, in the face of the impact of the global pandemic, the reduction in consumption in foreign markets will affect the demand for domestic orders. Even if the resumption of work and production can be fully realized, there will still be a phenomenon that the production capacity cannot be restored in a percentage. This is the main reason leading to the decline in exports. China's manufacturing industry is an important part of the global industrial supply chain. The pandemic caused a cliff-like decline in exports of some Chinese goods and even a lack of supply, which also caused the entire international production line to break [19].

From the perspective of the whole year, the total export volume has increased compared with last year. The export of anti-pandemic materials in 2020 has increased significantly. Medical instruments and equipment increased by $40.5 \%$ year-on-year, textile yarns, fabrics, and products were $29.2 \%$, and Chinese herbal medicines and Chinese patent medicines were 2.2\% [20]. At the same time, China actively provides humanitarian assistance to the international community, provides timely and decisive assistance to the international community within its capacity, and provides material support for the world's fight against the pandemic. This is also for a better foreign market. When assisting other countries in helping them tide over the difficulties, the foreign economic environment is better, and there is more market demand, which is more conducive to foreign trade cooperation.

\section{Prospects for the Future Development of China's Economy}

The "China Economic Bulletin: From Recovery to Rebalancing" published by the World Bank predicts that China's economic growth will rebound to $7.9 \%$ in 2021 . The organization predicts that the global economy will shrink by $5.2 \%$ in 2020 , the worst recession since World War II, and the proportion of economies with a decline in per capita output will reach the highest level since 1870 . And this year China will be the only country with positive growth among the world's major economies [21].

The GDP prediction research group of the Chinese Academy of Sciences' Forecast Science Research Center predicts that China's economic growth rate will reach about $8.5 \%$ in 2021, and the economic growth rate will return to $6 \%$ in 2022 . The growth rate of the added value of the secondary industry is expected to be $9.5 \%$, showing a recovery growth [22]. As the domestic pandemic is better controlled and the per capita disposable income of residents increases, it is expected that China's consumption will continue to recover, becoming the main force driving economic growth. The impact of relevant investment policies continues, especially under the strong support of the "14th Five-Year Plan" for the development of high-tech industries, investment in high-tech industries has become the driving force of overall investment growth, and the role of investment in economic growth has been further consolidated. In terms of foreign trade, the COVID-19 vaccine will be launched in 2021, and the pandemic in developed economies such as the European Union, the United States, and Japan may be better controlled; the central government is fully aware of the series of problems caused by the imbalance of foreign trade, and vigorously promotes the import of goods and services [23].

Combining the above two viewpoints, China's GDP growth rate is expected to be around $8 \%$ in 2021. The GDP growth rate will be affected by the recovery of the global economy. If the global pandemic can be effectively controlled, it will provide a better environment for economic 
development and also benefit China's import and export trade. Conversely, if the pandemic continues to spread and the world economy continues to shrink, it will create an even worse external environment for China. The development of the global economy is also an important factor affecting the Chinese economy.

\section{Conclusion}

This article analyzes China's economic data under the pandemic in 2020, reflects China's economic development under the pandemic from the perspective of GDP, industrial production, social consumption, fixed assets, foreign investment and export trade, and analyzes the reasons for the changes in the data. Analysis of the data found that the pandemic's economic impact on China mainly occurred in the first half of the year. With the effective control of the pandemic, the data of major economic indicators in the second half of the year achieved positive growth. From a full-year perspective, the added value of industries above designated size has returned to the level before the pandemic; the total retail sales grew steadily; the growth rate of fixed assets and foreign investment turned from negative to positive; the total export of goods achieved growth. The annual GDP growth rate is expected to be around $8 \%$. Based on the above data analysis, we can get the following conclusions.

\subsection{Controlling the Pandemic is a Prerequisite for Economic Growth}

From the perspective of China's economic situation in 2020, controlling the pandemic is the key to economic recovery and growth. Only by controlling the spread of the pandemic can we create more room for economic development. In the early stage of the outbreak, the state adopted strict prevention and control measures to protect the people's lives. During this period, economic development and pandemic prevention and control are incompatible, and normal economic activities must make way for pandemic prevention and control. In the Post-pandemic era, the cases of the COVID-19 are within a controllable range, and most of the economic activities can be carried out when the pandemic prevention and control enter normalized management. At this stage, economic development and pandemic prevention and control are compatible. Therefore, only by controlling the pandemic, can we provide a safe and stable environment for economic growth, and protect people's lives while developing the economy.

Compared with other major economies in the world, China has taken appropriate preventive and control measures in response to the outbreak of the pandemic, effectively reducing the spread of the virus and controlling the spread of the pandemic. A global recession is inevitable. But how deep and long the downturn will be depending on the success of measures taken to prevent the spread of COVID-19. Among the 18 major economies in the world, China is the only one that has achieved positive economic growth.

\section{2 "New Infrastructure" is a Strong Driving Force for Post-pandemic Economic Development}

In the long run, as China's economy quickly enters the digital economy era, traditional infrastructure alone can no longer meet the needs of China's sustained economic development. After years of hard work, China has been at the forefront of the world in $5 \mathrm{G}$ communications and certain Internet technologies. New infrastructure is a conceptual category corresponding to traditional infrastructure construction. It mostly refers to infrastructure construction that will lead the next wave of technological revolution, such as $5 \mathrm{G}$ base stations, industrial Internet, electric vehicle charging piles, big data centers, urban rail transit, and the Internet of Things. Innovation is the fundamental driving force for the high-quality development of China's economy. It is also the commanding height of comprehensive national power competition under the difficult and complicated environment of the ebb of globalization and the rise of trade protection. It is the only way out for China to achieve overtaking on curves. This year the country has proposed a series of policies to encourage 
technological innovation and promote industrial upgrading. The guidance of these policies has enabled the rapid development of high-tech industries. With the concept of "domestic large-scale circulation as the mainstay" putting forward, China's domestic market will generate more demand in the future. Only by putting higher quality products and services on the market can a large-scale circulation of virtuous development be formed. Persevering in reform and innovation and overcoming the technical problems of "stuck neck" will become a potential driving force for economic development.

\section{3 "Double Cycle" is the New Pattern of China's Economic Development in the Future}

"Accelerating the construction of a new development pattern in which domestic and international cycles are the mainstay and the mutual promotion of domestic and international cycles" is the policy of China's future economic development. "Mainly focusing on the domestic big cycle" means changing the export-oriented economic development model formed under the "international big cycle" strategy, and building a dual-cycle starting point from both supply and demand. When global trade is decelerating or even shrinking, and the flow of factors is not smooth or even stopped, it is necessary to deepen the domestic market through the domestic cycle to improve economic development quality. China has a huge market size and is the world's most potential consumer market. China has more than 100 million market players, more than 170 million people with higher education or various professional skills, and a large-scale domestic demand market formed by 1.4 billion people, including more than 400 million middle-income groups. At present, China's consumption potential is still to be released. If the people's income increases, the market demand will be even greater. Relying on domestic demand will strongly support overall economic growth.

\section{References}

[1] Xu Xianchun, Chang Zihao, Tang ya. Statistics and data on the impact of the COVID-19 pandemic on China's economy. Economic Dynamics, no. 5, pp. 41-51, 2020.

[2] A spokesman for the National Bureau of statistics answers reporters' questions on the operation of the national economy in the first half of 2020, [online] Available: http:// www. stats. gov. cn/tjsj/ sjjd/ 202007/ t20200716_1776345.html.

[3] Preliminary accounting results of gross domestic product (GDP) in the fourth quarter and the whole year of 2020, [online] Available: http://www.stats.gov.cn/tjsj/zxfb/202101/t20210119_ 1812514.html.

[4] Macroeconomic performance, [online] Available: http://www.gov.cn/shuju/index.htm.

[5] Director of the National Bureau of statistics answers reporters' questions on the operation of the national economy in 2020, [online] Available: http://www.stats.gov.cn/tjjj/sjjd/202101/t20210118_.

[6] Yang Guangli, Sun Huiqing. Research on the relationship between macro tax burden and economic growth -- Also on the effect of COVID-19's tax reduction and tax reduction policy. Price Theory and Practice, pp. 1-4, 2021.

[7] Research group of "analysis and prediction of China's macroeconomic situation" of national economic Engineering Laboratory of Northeast University of Finance and economics, Zhou Tianyong, Xu Wenli. China's economy grows in global recession. Economic Information Daily, pp8, 2021.

[8] The added value of industries above Designated Size will increase by $4.8 \%$ in June 2020, [online] Available: http://www.stats.gov.cn/tjsj/zxfb/202007/t20200716_1776195.html.

[9] The added value of industries above Designated Size will increase by $7.3 \%$ in December 2020, [online] Available: http://www.stats.gov.cn/tjsj/zxfb/202101/t20210118_1812427.html.

[10] Director of the National Bureau of statistics answers reporters' questions on the operation of the national economy in 2020, [online] Available: http://www.stats.gov.cn/tjsj/sjjd/202101/t20210118_.

[11] New infrastructure promotes new formats, [online] Available: http://www.xinhuanet.com/fortune/2020$04 / 21 /$ c $1125883732 . h t m$.

[12] In June 2020, the total retail sales of social consumer goods decreased by $1.8 \%$, [online] Available: http://www.stats.gov.cn/tjsj/zxfb/202007/t20200716_ 1776198.html. 
[13] He Chengying, Wen Yuechun, Chang Yali, Geng Xiaoxu. Measurement and analysis of the impact of new coronavirus pneumonia on China's economy. Research on Quantitative Economy, Technology and Economy, no.5, pp. 3-22, 2020.

[14] How can digital economy become a new driving force. People's Forum, no.1, pp. 10-11, 2021.

[15] China's fixed asset investment (excluding farmers) From January to December 2020 will increase by 2.9\%, [online] Available: http://www.stats.gov.cn/tjsj/zxfb/202101/t20210118_1812430.html.

[16] macro prediction research group of China Institute of economic thought and practice, Tsinghua University, Li Daokui. Analysis of China's Macro Economic Situation and Future Orientation. Reform, no.1, pp. 1$17,2021$.

[17] In the first half of the year, China's total import and export value of goods trade was 14.24 trillion yuan, [online] Available: http://js.people.com.cn/n2/2020/0715/c359574-34156738.html.

[18] In 2020, China's total import and export value will reach 32.16 trillion yuan, with a year-on-year increase of 1.9\%, [online] Available: http://www.gov.cn/xinwen/2021-01/15/content_5580075.htm.

[19] Shen Guobing. Impact of novel coronavirus pneumonia on China's foreign trade and employment and its rescue measures. Journal of Shanghai Foreign Economic and Trade University, vol.27, no. 2, pp. 16-25, 2020.

[20] volume value table of national key export commodities in December 2020 (US dollar value), [online] Available: http:/www. customs. gov.cn/ customs/ 302249/ zfxxgk/ 2799825/ 302274/ 302275/3511716/ index. html.

[21] China's economy in the epidemic era has become the world's biggest bright color, [online] Available: https: // guancha.gmw.cn/2020-12/31/content_34509634.htm.

[22] research group of GDP forecasting, Center for Forecasting Science, Chinese Academy of Sciences, Chen Xikang, Yang Cuihong, Zhu kunfu, Wang Huijuan, Li Xinru, Jiang Qingyan. 2021: China's economic growth will pick up rapidly. China Economic Times, pp. 4.

[23] Chen Xikang, Yang Cuihong, Zhu kunfu, Wang Huijuan, Li Xinru, Jiang Qingyan. Forecast analysis and policy suggestions on China's economic growth rate in 2021. Proceedings of the Chinese Academy of Sciences, vol. 36, no.1, pp. 37-46, 2021. 